\title{
Biology and molecular characterization of necroviruses affecting Olea europaea L.: a review
}

\author{
Maria do Rosário Félix • Carla M. Reis Varanda • \\ Maria Ivone E. Clara
}

Accepted: 14 November 2011 /Published online: 12 December 2011

(C) KNPV 2011

\begin{abstract}
Three necroviruses, family Tombusviridae, are known to infect Olea europaea L., Olive latent virus 1 (OLV-1), Olive mild mosaic virus (OMMV) and Tobacco necrosis virus D (TNV-D), often asymptomatically. OLV-1 has a wide geographical distribution whereas that of OMMV and TNV-D is not known as their discovery is recent, dating from 2005 and 2009, respectively. OMMV has received special attention because of its origin, likely to have resulted from a recombination event between TNV-D, with which it shares a coat protein (CP) amino acid identity of $86 \%$ and OLV-1 sharing an RNA-dependent RNA polymerase amino acid identity of $91 \%$. Due to these properties OMMV and TNV-D are indistinguishable by serology or Reverse Transcription - Polymerase Chain Reaction assays that use primers hybridizing in the $\mathrm{CP}$ gene region, rendering ambiguous earlier TNV-D identifications based on such tests. OLV-1 and OMMV are transmitted through the soil to roots of host plants in the absence of any vectors but the
\end{abstract}

M. d. R. Félix · C. M. R. Varanda • M. I. E. Clara

Laboratório de Virologia Vegetal, Instituto de Ciências

Agrárias e Ambientais Mediterrânicas,

Universidade de Évora,

Apartado 94,

7002-554 Évora, Portugal

M. I. E. Clara $(\bowtie)$

Departamento de Fitotecnia, Universidade de Évora,

Apartado 94,

7002-554 Évora, Portugal

e-mail: iclara@uevora.pt transmission rate of OMMV increases to more than double in the presence of Olpidium brassicae zoospores that vector this virus in an in vitro manner. A point mutation leading to an amino acid substitution located in an inner region of the virion is responsible for the loss of biologically assisted transmission, probably by altering the particle conformation rendering the binding site inaccessible to the zoospore receptors. The field occurrences of necrovirus multiple infections are common and increase the chances for recombination events, the epidemiological implications of which are still uncertain. The biological and molecular properties of the necroviruses identified in olive trees are the main focus of this review.

Keywords OLV-1 $\cdot$ TNV-D $\cdot$ OMMV Olea europaea Olpidium brassicae

\section{Introduction}

Olea europaea L. has long been a socio-economically important crop in countries in southern Europe, North Africa and the Middle East and its cultivation has been expanding for the last 20 years to other areas characterized by Mediterranean (California, Chile, South Africa, Australia) or Mediterranean-like (e.g. Argentina, China, India) climates. Its importance comes mainly from the well recognized human health benefits associated to the consumption of olive oil but other derived products as preserved table olives, 
cosmetics and, to some extent, microorganisms and metabolites present in the brine of the olive preservation process show potential for pharmaceutical and other industrial applications. The expansion to new countries has increased the demand for certified olive nursery stock meeting the specific requirements of the European Union (EU) as well as others imposed by the importing source.

EU has enacted regulation on the marketing of fruit plants intended for fruit production, namely the Commission Directive 93/48/EEC (EEC Directive, 1993). The Conformitas Agraria Communitatis category, applicable to olive plant material, demands that plants must be free of all viruses as they are considered harmful or quality affecting organisms (Annex to the 93/48/EEC). Such a plant health condition requirement is generally viewed by the researchers working on the field as too restrictive, especially if compared to that applicable to other plant species, since the viral effects on olive quality are not clear. Yet, the legislation had the merit in that, to comply with the standards laid down by the directive above and also to meet phytosanitary specific requirements of importing countries, viral surveys have been conducted in various countries. To examine the health status of olive orchards, appropriate and sensitive viral diagnostic tools were developed for certification purposes and cultivar improvement programs were started to establish mother plants free from virus and other pathogens. In general, high levels of viral infection were detected in many countries (Saponari et al. 2002a; Varanda et al. 2006, 2010; El Air et al. 2011). Characterization of the virus species infecting olive led to the identification of 15 different species, belonging to 8 different genera, and 3 species of undetermined genus. Out of the 15, three are necroviruses: Olive latent virus 1 (OLV-1), recorded for the first time by Gallitelli and Savino (1985) in Italy, Olive mild mosaic virus (OMMV), and Tobacco necrosis virus D (TNV-D) definitively identified by Cardoso et al. in 2005 and 2009, as a new species and as infecting a new host, respectively. These viruses share interesting genomic features, occur frequently in mixed infections in Portuguese olive orchards, and OMMV shows positive interaction with a soil fungus with potential epidemiological impact. A comparative analysis of their genome, molecular organization, diagnosis, and virus-vector interactions are reviewed here.

\section{Biological and biochemical properties}

Host plants

OLV-1 was recovered from olive trees, in Italy, showing low vigour, defoliation, bifurcation and fasciation of branches, as well as from symptomless trees (Gallitelli and Savino 1985; Martelli et al. 1996; Merciega et al. 1996), and since then its presence has been detected in other countries (Table 1). Additionally, OLV-1 can infect a variety of experimental hosts usually causing local necrosis. Systemic symptoms are exhibited by Nicotiana benthamiana and $N$. occidentalis, following mechanical inoculation with almost all OLV-1 isolates with the exception of the Portuguese isolate GM6 that does not invade systemically these indicator plants (Félix et al. 2005a; Félix et al. 2007). Infection in olive is likely systemic as the virus was detected in flowers, fruits, seeds and seedlings (Lobão et al. 2002; Saponari et al. 2002b). The virus was also found in Turkey infecting several citrus species either without symptoms or associated to the chlorotic dwarf disease characterized by leaf deformation and interveinal chlorosis (Çinar et al. 1993; Martelli et al. 1996). In Japan OLV-1 was diagnosed in tulips exhibiting foliar mottling and yellow streaks (Kanematsu et al. 2001), and more recently, in Poland, it was detected in greenhouse tomatoes showing localized leaf necrosis (Borodynko et al. 2010).

OMMV was first recovered from fruits of an olive tree, belonging to a genotype collection of the Portuguese cultivar 'Galega vulgar', exhibiting mild mosaic symptoms. The properties initially analysed biological, biochemical, serological and coat protein (CP) gene sequence - indicated it to be a TNV-D isolate being then designated as GP isolate (Félix and Clara 1998; Louro 2004; Cardoso et al. 2004). However, sequencing of the complete genome showed a high identity of the CP gene with that of TNV-D and a high identity of the RNA dependent RNA polymerase (RdRp) gene with that of OLV-1. Application of the criteria for necrovirus species demarcation led to its classification as a new species for which the name Olive mild mosaic virus was coined (Cardoso et al. 2005). This finding renders doubtful previous identifications of TNV-D based solely on serology or PCR amplification of CP gene sequences. In fact, recent analysis of genome 
Table 1 Olive necrovirus frequency and geographical distribution

\begin{tabular}{|c|c|c|c|c|c|c|c|}
\hline \multirow[t]{2}{*}{ Country } & \multirow[t]{2}{*}{ Site $\left(n^{0}\right)$} & \multirow[t]{2}{*}{ Sample $\left(n^{o}\right)$} & \multirow[t]{2}{*}{ Diagnostic techniques (template in PCR) } & \multicolumn{3}{|c|}{ Percentage of infection } & \multirow[t]{2}{*}{ Reference } \\
\hline & & & & OLV-1 & OMMV & TNV-D & \\
\hline Egypt & 5 & 300 & RT-PCR (TNA) & 5.7 & nt & $\mathrm{nt}$ & Youssef et al. 2010 \\
\hline Italy & 1 & $31^{\mathrm{a}}$ & Molecular hybridization (dsRNA) & 8.3 & nt & $\mathrm{nt}$ & Saponari et al. $2002 b$ \\
\hline Lebanon & 76 & 300 & RT-PCR (TNA) & 8.3 & nt & $\mathrm{nt}$ & Fadel et al. 2005 \\
\hline \multirow[t]{2}{*}{ Portugal } & 1 & 54 & RT-PCR (dsRNA) & 22.1 & 27.8 & 7 & Varanda et al. 2010 \\
\hline & 1 & 161 & RT-PCR (dsRNA) & 0.6 & \multicolumn{2}{|c|}{$21^{\mathrm{b}}$} & Varanda et al. 2006 \\
\hline Syria & 80 & 300 & RT-PCR (?) & + & nt & $\mathrm{nt}$ & Al Abdullah et al. 2005 \\
\hline Tunisia & 2 & 175 & RT-PCR (TNA) & 34.3 & nt & nt & El Air et al. 2011 \\
\hline
\end{tabular}

${ }^{\text {a }}$ Subset of $25 \%$ of the samples that tested dsRNA positive

b Infection due to OMMV, TNV-D or both

+Virus present but not quantified

nt Not tested

TNA Total nucleic acid; dsRNA: Double-stranded RNA; PCR: Polymerase Chain Reaction; RT-PCR: Reverse TranscriptasePolymerase Chain Reaction

? Template not specified

sequences (GenBank accession nrs EF201605, EF201606 and EF201607) of the virus causing the Augusta disease of tulips in The Netherlands, characterized by leaf and flower necrotic spots and stripes, stunting and premature plant death, assumed to be the TNV serotype D since 1949, revealed a remarkable high identity, 98\%, with the OMMV genome and led to a taxonomy revision of the causal virus (Pham et al. 2009). So far olive and tulip are the only natural known hosts of OMMV. The virus infects a variety of experimental hosts where it causes mainly local lesions, except if inoculated to $N$. benthamiana at very young stages where it moves systemically and may cause extensive necrosis and plant death (Cardoso 2009). Discrimination between OMMV and TNV-D is now possible through the application of a specific RT-PCR assay designed by Varanda et al. (2010).

A TNV-D isolate, denoted TNV-D ${ }^{\mathrm{P}}$, was recovered from a symptomless olive tree of the cultivar 'Verdeal Alentejana' growing in south Portugal, through mechanical inoculation of fruit extracts onto Chenopodium murale plants where it induced local necrosis. Its identification was based on the overall genome sequence identity with that of TNV-D (English isolate), obtained from bean plant (Coutts et al. 1991) and of TNV-D ${ }^{\mathrm{H}}$ (Hungarian isolate), obtained from tobacco plants (Molnar et al. 1997), 94.8\% and $82.9 \%$, respectively (Cardoso et al. 2009). Several
TNV-D serotypes have been referred to in the literature infecting a variety of different host plants, including tulips in Japan from the same site where OLV-1 infections were recorded (Kanematsu et al. 2001). So far only the above mentioned three isolates have been completely sequenced and thus the others identified as such in earlier literature may turn out to be either TNV-D or OMMV.

\section{Biochemical properties}

OLV-1, OMMV and TNV-D have similar general properties as they belong to the necrovirus genus. They are easily purified from infected herbaceous hosts following an identical protocol that uses either $0.1 \mathrm{M}$ sodium phosphate in the presence of sodium ascorbate, or $0.1 \mathrm{M}$ ammonium citrate buffer for homogenization, organic solvents for clarification, precipitation by polyethylene glycol, differential centrifugation cycles and further ultracentrifugation in sucrose density gradient columns. This procedure yields about $1.1 \mathrm{mg}$ of OLV-1, $0.6 \mathrm{mg}$ of OMMV and $0.4 \mathrm{mg}$ of TNV-D from $100 \mathrm{~g}$ of infected tissue. The viruses sediment as a single infectious component at ca $111 \mathrm{~S}$. The particles are isometric, $28-30 \mathrm{~nm}$ in diameter, when viewed under an electron microscope (Martelli et al. 1996; Félix 2007; Cardoso 2009). 
Upon virus denaturation and analysis of its moieties the RNA genome is shown to be a monopartite linear positive-sense single stranded molecule of $3.6-3.8 \mathrm{~kb}$ encoding 5-6 proteins. The coat protein is made up of a single peptide sized $c a$ $30 \mathrm{kDa}$. Each particle is made up of 180 identical subunits with $\mathrm{T}=3$ icosahedral symmetry. Viral replication in the infected plant cells involve the synthesis of three double stranded (ds) RNAs, 3.7 $\mathrm{kbp}, 1.5 \mathrm{kbp}$, and $1.3 \mathrm{kbp}$, corresponding to the full genome and to two smaller subgenomic RNAs (sgRNAs), respectively (Regenmortel et al. 2000; Cardoso et al. 2004; Félix et al. 2005a).

\section{Genome organization}

The OLV-1 olive isolate GM6 RNA is $3702 \mathrm{nt}$ long (DQ083996), three nucleotides longer than that of citrus and tomato isolates (NC_001721 and GU326337, respectively). The genome organization is similar for all three isolates with five functional Open Reading Frames (ORFs) encoding five proteins and the strategies employed for genome expression include stop codon suppression, overlapping of reading frames and subgenomic messenger RNAs.

In the olive GM6 isolate, ORF1 follows a 5', end non coding leader sequence of $60 \mathrm{nts}$, begins at the first AUG codon in position 61 and extends to the UAG stop codon in position 666, encoding a pre-read-through $23 \mathrm{kDa}$ (p23) peptide. The read-through of the leaky amber termination codon generates an $82 \mathrm{kDa}$ (p82) product which contains the GDD (Gly-Asp-Asp) motif and other typical polymerase sequences suggesting that it is the virus RdRp (Poch et al. 1989). Both p23 and p82 are expressed directly from the viral genomic RNA and are indispensable for its replication, as inferred from site-directed mutagenesis experiments (Pantaleo et al. 1999). ORF2 and ORF3 are located in the central region of the genome and encode two small peptides with $8 \mathrm{kDa}(\mathrm{p} 8)$ and $6 \mathrm{kDa}(\mathrm{p} 6)$, respectively. These are expressed via a bi-cistronic subgenomic RNA (sgRNA1) 1519 nts long, are involved in virus cell-to-cell movement and in systemic infection, as shown by site-directed and deletion mutagenesis (Pantaleo et al. 1999). Additionally, the p6 peptide contains a predicted trans- membrane motif that may have a membrane docking function (Castellano et al. 2005). The ORF4 occupies the $3^{\prime}$ end of the genome and codes for the $30 \mathrm{kDa}$ $\mathrm{CP}$, which is translated from a $1237 \mathrm{nt}$ sgRNA2. Besides its role in capsid formation, p30 appears to assist in the systemic spread of the citrus isolate in $N$. benthamiana plants as mutations induced in the $\mathrm{R}$ (RNA-binding) and S (shell) CP domains, and the deletion of nt in position 3297 that causes a frame shift and a shortening in 10 amino acids (aa) of the viral $\mathrm{CP}$ at its $\mathrm{C}$-terminal domain, prevents the systemic invasion of those plants (Pantaleo et al. 2006). In the CP S domain of four OLV-1 isolates (citrus, GM6 olive, tulip and tomato) the ' $\mathrm{S}$ ' signature consensus pattern, consisting of 26 amino acids conserved among small icosahedral plant viruses is easily recognized (Falquet et al. 2002; Félix et al. 2005a; Borodynko et al. 2010). It was found that in all those isolates the amino acid Leu occupies the $17^{\text {th }}$ position in the signature sequence, contrary to that exhibited by other necrovirus species. Thus the sequence has been proposed to be enunciated as follows: [FYW]-x-[PSTA]-x(7)-G-x-[LIVM]-x[LIVM]-x-[FYWIL]-x(2)-D-x(5)-P (Félix et al. 2005a). The 3' end UTR from GM6 isolate is 253 nt long (Félix et al. 2005b). The schematic representation of OLV-1 RNA organization and the relative position of the five ORFs are shown in Fig. 1.

The complete genome sequence of the olive isolate TNV-D ${ }^{\mathrm{P}}$ is $3761 \mathrm{nt}$ long (FJ666328), it shares an overall sequence identity of $94.8 \%$ with that of TNVD English isolate (D00942) and 82.9\% with that of TNV-D ${ }^{\mathrm{H}}$ Hungarian isolate (NC_003487), whereas the nucleotide sequence identity to those other necroviruses are near or below 50\% (Cardoso et al. 2009). TNV-D genome has six predicted ORFs (Fig. 1), as the English and Hungarian TNV-D isolates. The 5'-proximal ORF1 begins at $39 \mathrm{nt}$ and ends at $647 \mathrm{nt}$ encoding a putative 202 aa peptide with a molecular mass of $22 \mathrm{kDa}(\mathrm{p} 22)$. The readthrough of the amber stop codon located in the triplet 645-647, to the $2216 \mathrm{nt}$, generates the ORF1 RT that encodes a predicted 725 aa protein with $82 \mathrm{kDa}(\mathrm{p} 82)$. This protein was identified as the RdRp by sequence comparison analysis, and the presence of catalytic RdRp domain of positive-strand RNA viruses (Cardoso et al. 2009). ORFs 2, 3 and 4, are located centrally in the genome, each predicted to encode small peptides with about $7 \mathrm{kDa}$ designated $\mathrm{p} 7_{1}(62$ 
Fig. 1 Genome structure of olive necroviruses (OLV-1 - Olive latent virus 1; OMMV - Olive mild mosaic virus; TNV-D Tobacco necrosis virus D). ORFs are shown as boxes with predicted sizes indicated above or below RT: readthrough; RdRp: RNA polymerase RNA dependent; CP: Coat protein

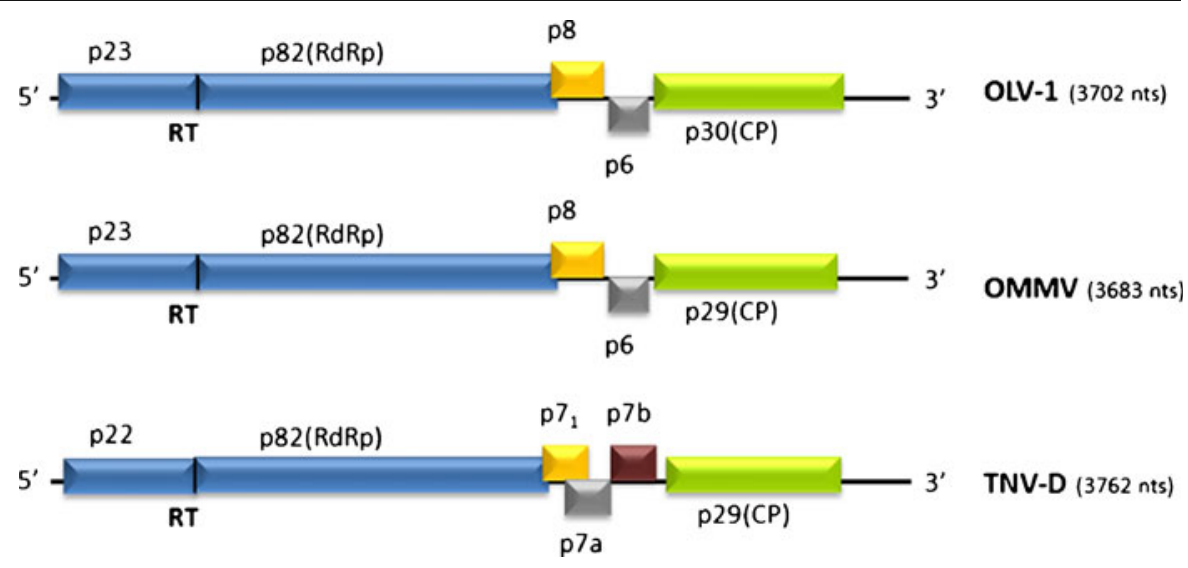

aa), p7a (65 aa) and p7b (66 aa) respectively, which are associated to the viral cell-to-cell movement. The ORF5, located in the 3'-proximal region encodes a putative $29 \mathrm{kDa}$ protein with 268 aa, identified as the virus $C P$ which contains the ' $S$ ' sequence signature of small icosahedral plant viruses, as well as the four conserved aa identified as $\mathrm{Ca}^{2+}$ binding sites (Cardoso et al. 2009). The same authors have noted the remarkable sequence conservation among the three TNV-D isolates, English, Hungarian and Portuguese, in spite of their different natural hosts and geographic origin.

OMMV was initially identified as a TNV-D isolate GP (Cardoso et al. 2004) but after complete sequencing it was concluded that the virus was a distinct species (Cardoso et al. 2005). OMMV genomic RNA organization is similar to that of the other members of the Necrovirus genus (Fig. 1). It has 3683 nts (AY616760) and 5 ORFs. The 5'-proximal ORF1 begins at $60 \mathrm{nt}$ and ends at $668 \mathrm{nt}$ encoding a peptide sized 202 aa (p23). ORF1 RT (designated ORF2 by some authors) results from the read-through of the amber stop codon (nt 666-668), a genome strategy common to all three olive necroviruses, to the 2234 $\mathrm{nt}$, encodes a $82 \mathrm{kDa}$ protein predicted to be the viral RdRp. The ORF3 (nt 2218-2439) overlaps ORF1 RT by $17 \mathrm{nts}$ and encodes a 73 aa peptide (p8) and ORF 4 (nt 2443-2613) encodes a 56 aa peptide (p6) (Cardoso et al. 2005). These two small proteins are predicted to be involved in virus movement based on the high aa sequence identity with the OLV-1 movement proteins p6 and p8. The 3'-proximal ORF5 (nt 2636-3445) encodes a 269 aa peptide with $29 \mathrm{kDa}$ (p29) that was identified as the virus $\mathrm{CP}$ (Cardoso et al. 2004).
The deduced OMMV CP amino acid sequence has $86.2 \%$ identity with that of TNV-D, explaining their similar positive serological reactions with various TNV antisera, and 40.7\% identity with that of OLV-1 (Cardoso et al. 2004); whereas RdRp shows a high identity, 91.2\%, with that of OLV-1 and very low with that of TNV-D, 33.6\%. The p6 and $\mathrm{p} 8$ of OMMV show high identity with those of OLV-1, 87\% and $100 \%$, respectively (Félix 2007; Cardoso et al. 2005) (Fig. 2). Due to these features, it is highly probable that OMMV originated from a recombination event that occurred during simultaneous replication in a host cell, likely through a replicase-driven switching mechanism involving TNV-D and OLV-1 RNA templates. Such an occurrence is further supported to some extent by the findings of natural necrovirus mixed infections frequently detected in olive trees in Portugal (Varanda et al. 2010).

\section{Detection of necroviruses in olive trees}

Biological assays

The only biological assay to reveal viruses in olive is mechanical transmission to herbaceous hosts. There are no differential woody indicator hosts to facilitate virus detection or identification. Olive fruits, flowers and young leaves, roots and stems are good virus sources to mechanically inoculate indicators as: Chenopodium amaranticolor, C. quinoa, C. murale, $N$. benthamiana, $N$. clevelandii, $N$. glutinosa, $N$. langsdorffii, and $N$. tabacum. Most frequently used are $N$. benthamiana, 
Fig. 2 Phylogenetic trees generated from alignments of RdRp (a) and CP (b) sequences of various necrovirus species using the neighbor-joining method. TNV-D ${ }^{\mathrm{P}}$, Portuguese isolate (FJ666328) TNV-D, English isolate (D00942); TNV-D ${ }^{\mathrm{H}}$, Hungarian isolate (NC_003487); OMMV (NC_006939); OLV-1citrus, Turkish isolate (NC_001721); OLV-1olive, Portuguese isolate (DQ083996); OLV-1 tomato, Polish isolate (GU326337), OLV-1tulip, Japanese isolate (AB061815), TNV-A (NC_001777); TNV-A ${ }^{\text {ch }}$, Chinese isolate (AY546104); TNV-A $^{\mathrm{H}}$, Hungarian isolate (GQ221829); Beet black scorch virus (BBSV) (NC_004452); BBSV ${ }^{\mathrm{USA}}$, American isolate (EF153268); and Leek white stripe virus (LWSV) (NC_001822). Numbers at each node indicate the bootstrap confidence value
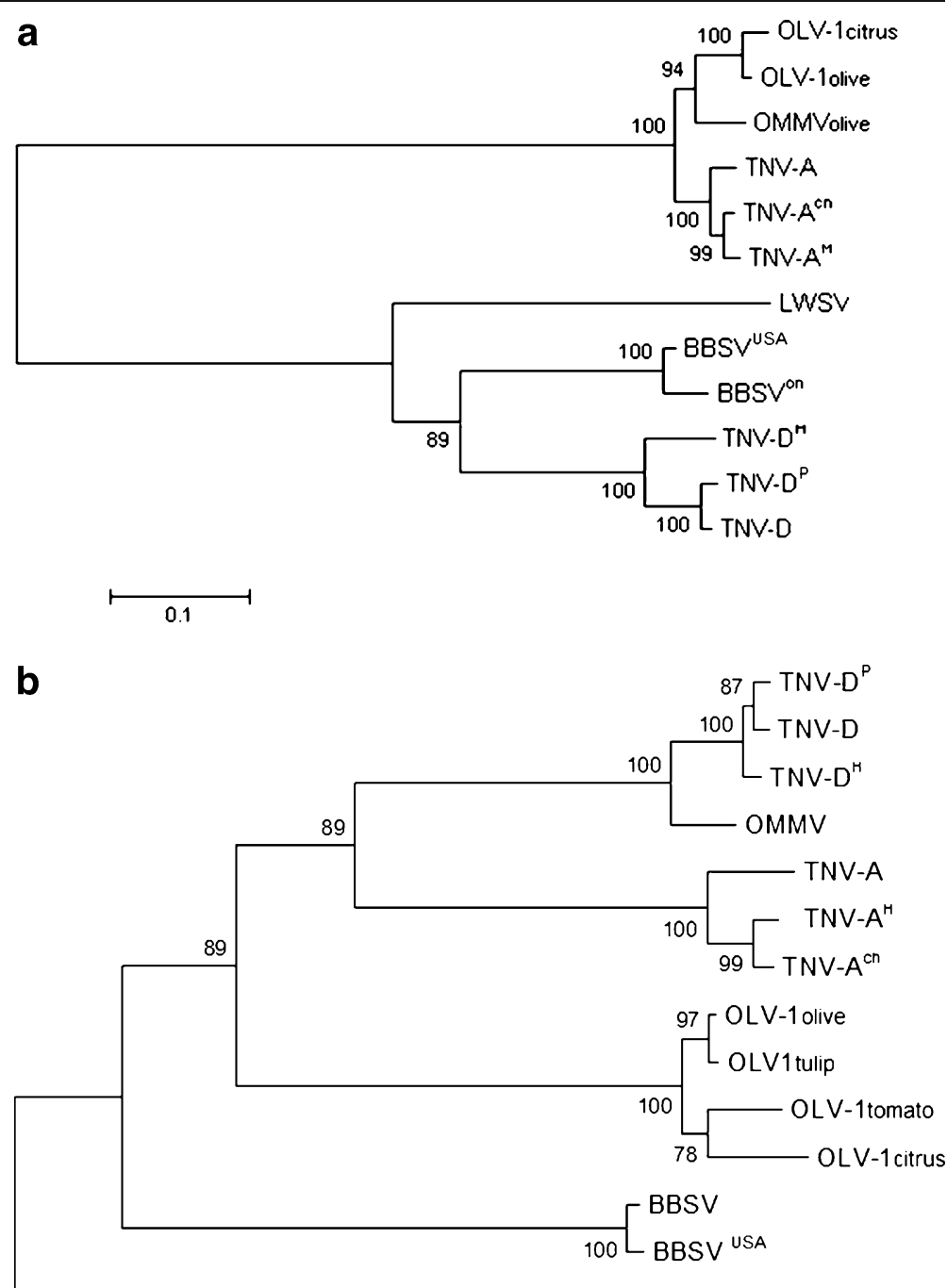

LWSV
C. murale and $C$. quinoa as they react strongly to olive necrovirus infections (Félix and Clara 2008). Main disadvantages of this assay are the variable amounts of virus in the olive tissues throughout the year and content in virus inactivator compounds that may lead to erratic and unreliable results. Yet it has been useful in past surveys aiming at sanitary selection of vegetative material in Portugal, where mechanically transmissible virus were found in up to $100 \%$ of samples in several sites and allowed the recovery of isolate collections of the three necrovirus species maintained in our laboratory for further studies (Clara et al. 1997; Martelli 1999; Félix et al. 2002; Félix and Clara 2008).
Serological assays

Currently, the enzyme linked immunosorbent assay (ELISA) (Clark and Adams 1977) has little use in detecting olive necroviruses directly from olive extracts due to the viral low concentration, irregular virus distribution in the tree and throughout year, and to the presence of substances interfering with the test, often leading to contradictory results. However, some of these difficulties may be overcome in part by using concentrated partially purified virus from olive material as test samples. On the other hand it is very useful for virus identification in infected indicator hosts, except for TNV-D and OMMV whose CP epitopes 
are highly similar thus testing positive with the same antiserum.

\section{Double-stranded RNA analysis}

Necrovirus replication strategy includes the cell synthesis of specific dsRNA molecules corresponding to the genomic and to two subgenomic replicative RNAs, the analysis of which provides an indication of their presence.

dsRNAs can be extracted from 15 to $35 \mathrm{~g}$ samples of olive tissues, as cortical scrapings of 2-year stems or fruits harvested in spring or fall seasons, following the procedure of Grieco et al. (2000) and Saponari et al. (2001) and analysed by gel electrophoresis. This technique has the advantage of not being interfered with by naturally occurring phenolic compounds in olive tissues, and has been successfully applied in evaluating the sanitary status of olive cultivars (Martelli et al. 1995; Rei 1995; Savino et al. 1996; Sabanadzovic et al. 1999). However, studies carried out by Varanda et al. (2006, 2008) showed that necrovirus dsRNAs occur in field trees at concentrations below the resolution limit of this technique. Its application to a collection of the cv 'Negrinha do Freixo' showed that dsRNAs fractions extracted from stems of 161 trees did not reveal the presence of any such molecules when analysed by gel electrophoresis, but their use as templates in specific RT-PCR clearly demonstrated necrovirus infections in 35 of those trees. Therefore dsRNA analysis, by itself, is not accurate in revealing necroviruses in olive trees (Varanda et al. 2006, 2008).

\section{RT-PCR assays}

Single and multiplex RT-PCR, in one or two steps and RT-nested-PCR formats have been optimized for olive virus diagnosis, following the design of virus specific primers (Martelli et al. 1996; Varanda et al. 2010) that enable high specificity and sensitivity, since as little as $10 \mathrm{fg}$ of OLV-1 have been detected (Grieco et al. 2000). The virus identification is based on the size of the specific amplicon generated by the PCR step of the assay, observed in gel after electrophoresis. RTnested-PCR is more sensitive than RT-PCR but the procedure presents risk of contamination that may lead to erroneous false positives (Pantaleo et al. 2001). The primers useful for necrovirus identification are indicated in Table 2. Those previously designed by Cardoso et al. (2004) hybridize within the CP gene region not discriminating between OMMV and TNV$\mathrm{D}$, but they are useful when the aim is to detect viral presence as is the case in sanitary selection programs (Loconsole et al. 2010). Total nucleic acids (TNA) extracted from as little as $0.1 \mathrm{~g}$ of infected tissues by means of commercial kits or denatured dsRNAs purified from 10 to $35 \mathrm{~g}$ of plant material are the best templates to use in RT-PCR (Fig. 3) (Varanda et al. 2009). The latter often gives more accurate results as the sample amount is much higher and representative, being preferred for small-scale sanitary screening of olive material, as the dsRNA isolation is a lengthy process. Its application to screen a collection of 54 olive trees of the cultivar 'Galega Vulgar' showed 17 with multiple infections: OMMV infected 15 trees (5 singly and 10 mixed), OLV-1 was present in 12 trees ( 2 singly and 10 mixed) and TNV-D affected 4 trees, all in mixed infections (Varanda et al.
Table 2 Primers used in RT-PCR assays for diagnosis of olive infecting necrovirus

\begin{tabular}{llllc}
\hline Virus & Primer & Position & Sequence 5'-3' & $\begin{array}{c}\text { Amplicon } \\
\text { (bp })\end{array}$ \\
\hline OLV-1 & PB & $2720-2738$ & TTTCACCCCACCAAATGGC & 747 \\
& PA & $3448-3466$ & CTCACCCATCGTTGTGTGG & \\
OMMV/ & GPint5' & $3022-3042$ & GTGTTCAGTCATATACATACC & 257 \\
TNV-D & GPint3' & $3259-3277$ & GCCTATTGTGCTGTACCAC & \\
OMMV & OMMVd5' & $1857-1875$ & CCGTGCCAAACACAATCTC & 934 \\
& OMMVd3' & $2771-2791$ & CCTAGATCTTCTGGGCTAAGC & \\
TNV-D & TNVDd5' & $303-322$ & GTAGGTGACAAGGACGCTGA & 278 \\
& TNVDd3' & $560-581$ & GGATAGCGACTTTTTAGCCGCT & \\
\hline
\end{tabular}




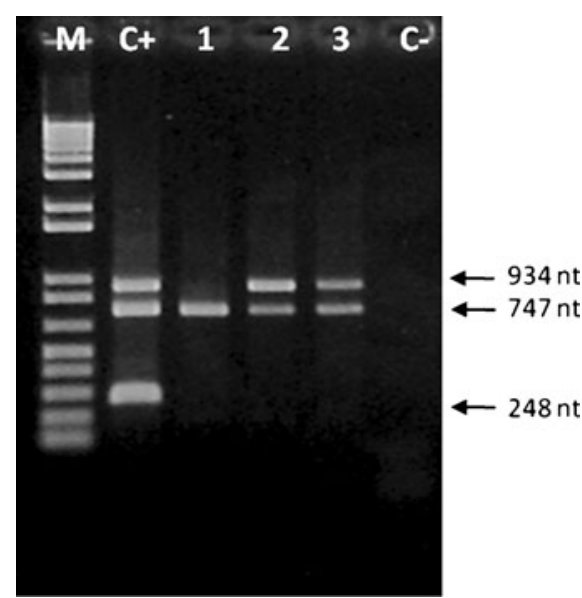

Fig. 3 Products of multiplex RT-PCR using dsRNA fraction extracted from olive trees as templates and specific primers for amplification of OMMV, OLV-1 and TNV-D, separated on a $1 \%$ agarose gel. Lane M: $1 \mathrm{~Kb}$ plus DNA ladder (Invitrogen); Lane $\mathrm{C}+$ : positive control obtained by using dsRNA extracted from an herbaceous plant multiple infected with OMMV, OLV1 and TNV-D; Lane 1-3: trees tested; Lane C-: olive uninfected control. Size of specific generated amplicons are indicated on the right

2010). A multiplex single step RT-PCR using TNA as template has recently been developed to diagnose nine viruses including the three necrovirus to apply in sanitary certification programs of olive cultivars in Italy (Loconsole et al. 2010).

The amplicons generated in RT-PCR assays can be further used to evaluate the natural diversity of a population of virus species isolates, by means of single strand conformation polymorphism (SSCP) (Rubio et al. 1996). Briefly, the amplified products are denaturated into single strand molecules prior to electrophoresis in polyacrilamide gels under nondenaturing conditions. This permits separation of the single strand molecules with different conformations and mobility in the gel. SSCP analysis applied to OLV-1 infected olive tissues, following RT-PCR assay that generated an amplicon sized $750 \mathrm{nt}$, showed five distinct electrophoretic profiles consisting of several single strand conformations, revealing a considerable genetic variability within a sequence that includes the $\mathrm{CP}$ gene in populations of OLV-1 isolates obtained from field trees (Félix et al. 2006a).

\section{Molecular hybridization}

Dot blot hybridization using 3' digoxigenin (DIG) labelled specific riboprobes has been used in the identification of several olive viruses including OLV-1. Of the substrates tested, plant sap, TNA and denatured dsRNAs, the latter proved to be best and a highly reliable detection method (Grieco et al. 2002). The combination of a single step multiplex RT-PCR and molecular hybridization to detect six viruses including OLV-1, was developed by Bertolini et al. (2001). Here the amplicons generated in RT-PCR were denatured, spotted on membranes and detected by 3' DIG labelled oligoprobes internally complementary to the amplicons, and that resulted in an increased sensitivity to $c a 10$ fold when compared to the RT-PCR assay in the prior step.

\section{Transmission}

Plant material

The major factor in virus maintenance is the use of infected olive vegetative material, as self rooted stem cuttings, which have been traded all over the world for centuries. OLV-1 was detected in olive flowers, fruits, seeds ( $82 \%$ in the cv Oliva rossa) and seedlings (36\% originated from infected seeds) (Saponari et al. $2002 b)$ suggesting that the use of infected seedlings as rootstock for grafting, still practiced by some nurseries in southern Italy, may be an important source of OLV-1 spreading in nature. OMMV and olive isolates of TNV-D have been found in stems and fruits and no information is available on their presence on flowers or seeds.

\section{Soil}

Plant growth substrates, either soil or aqueous suspensions, naturally or artificially contaminated with OLV-1 and OMMV are sources of infection, as demonstrated using herbaceous hosts. Studies revealed that $N$. benthamiana plants, previously leafinoculated with those viruses later release them into the vicinity of the roots, and new healthy plants transplanted into that substrate are capable of acquiring each virus through the root system. This is likely to occur by viral penetration via root wounds (Martelli et al. 1996; Félix et al. 2004, 2006b). Interestingly, if present in low density, OMMV cannot be acquired from the soil by the tobacco plants but if 
OLV-1 is also present in the soil then both viruses easily invade the roots spreading throughout the plant which becomes doubly infected and shows systemic symptoms. In this case both viruses do not remain restricted to the roots as is otherwise observed (Félix et al. 2006b). These data show that each virus does not suppress or out-compete the other, rather a synergism occurs. This may have important epidemiological implications if a similar phenomenon is found to occur within olive plants.

\section{Fungus vector}

Evaluation of Olpidium brassicae as a potential vector of OMMV was triggered by the observed high aa sequence identity of its CP, $86 \%$, with that of TNV$\mathrm{D}$ (Cardoso et al. 2005) which is known, since the 1960 s, to be vectored by a 'lettuce isolate' of $O$. brassicae (Kassanis and Macfarlane 1964; Temmink et al. 1970). The studies on this subject have been conducted by Varanda et al. (2011a, b), who used a single sporangial culture of a 'crucifer isolate', molecularly identified as $O$. brassicae, to demonstrate that its zoospores are capable of acquiring OMMV wild type in vitro and successfully transmit it to Chinese cabbage seedlings at rates that are more than double those obtained in the absence of zoospores (Table 3). Similar experiments, conducted with two other viruses as infectious as the wild type - a

Table 3 Soil transmissibility of OMMV, OMMVL11 and OMMV/OMMVL11 by means of $O$. brassicae ${ }^{(3)}$

\begin{tabular}{|c|c|c|}
\hline & \multicolumn{2}{|c|}{ Transmission efficiency (\%) } \\
\hline & average $^{(2)}$ & $\max -\min$ \\
\hline OMMV & 39 & $40-35$ \\
\hline OMMV + zoospores & 87 & $90-80$ \\
\hline OMMVL11 (3) & 32 & $35-30$ \\
\hline OMMVL11 + zoospores & 31 & $35-30$ \\
\hline OMMV/OMMVL11 ${ }^{(4)}$ & 29 & $30-25$ \\
\hline OMMV/OMMVL11 + zoospores & 31 & $35-30$ \\
\hline
\end{tabular}

\footnotetext{
(1) Adapted from Varanda et al., 2011, Table 1

(2) Average of 5 transmission experiments

(3) OMMVL11 - natural non O. brassicae transmissible mutant of OMMV

(4) OMMV/OMMVL11 - mutant obtained by substitution of OMMV CP gene by that of OMMVL11
}

naturally obtained variant OMMV L11 and a construct in which the CP of OMMV wt was replaced by that of the L11 variant - revealed that transmissibility was reduced to levels similar to those observed in the absence of the fungus (Table 3). This finding is in line with binding assay results showing that $7 \%(\mathrm{w} / \mathrm{w})$ OMMV virions bind to the zoospores, whereas practically no binding by the other two viruses was detected. Both sets of data clearly show an important role of the viral $\mathrm{CP}$ in mediating fungal transmission.

Further indication as to where the binding site lies within CP came from sequencing of OMMV wt and the L11 variant, that revealed two aa substitutions: Asn to Tyr and Ala to Thr, corresponding to the genome positions $3200 \mathrm{nt}$ and $3281 \mathrm{nt}$, respectively. Subsequent site-directed mutagenesis experiments in which separate mutations were induced in the OMMV wt, followed by fungal transmission, clearly showed that the change Asn to Tyr is largely responsible for the loss of virus transmissibility by $O$. brassicae. The use of comparative modelling based on the high resolution X-ray crystal structure of TNV (Oda et al. 2000) indicates that Asn to Tyr replacement is potentially located in the interior of the virion, whereas the Ala to Thr change is exposed at the particle surface (Fig. 4). Given the biological relevance of virus binding to zoospores and the high transmission efficiency it is proposed that the Asn to Tyr change alters the conformation of the virion in such a way that renders its binding sites inaccessible to the zoospores, drastically reducing transmission. On the other hand the location of the change Ala to Thr is not part of the binding domain and neither cause conformational alterations that affect transmission (Varanda et al. 2011b).

Mutations in the aa CPs sequence leading in decreased binding and transmission rates have been reported in a few virus fungal vector combinations, such as Cucumber necrosis virus (CNV, Tombusvirus) and Melon necrotic spot virus (Carmovirus) both transmitted by O. bornovanus (Kakani et al. 2001, 2004; Mochizuki et al. 2008). In most of these cases the aa mutation occurs in the external $\mathrm{CP}$ protruding $\mathrm{P}$ domain. Necrovirus lack the $\mathrm{P}$ domain and the aa mutation responsible for the loss of transmissibility of that OMMV mutant is located in the inner region of the virus particle. 
Fig. 4 Three-dimensional representation of the surface of the OMMV virus minimum contact unit, in two different views: the external face at the capsid, at the left side, and the internal face, at the right side. The central trimer is coloured in green, cyan and magenta, corresponding to chains $\mathrm{A}, \mathrm{B}$ and $\mathrm{C}$, respectively. a The external face and $\mathbf{d}$ the internal face, highlighting the central trimer (coloured as in the other figures), with other chains coloured in dark gray, in order to show the repeating unit. b The external face, showing the A216 residue and $\mathbf{c}$ the mutant $\mathrm{A} 216 \mathrm{~T}$ residue, with the sidechains rendered in spheres to distinguish them from the molecular surface. e The internal face, showing the N189 residue and $\mathbf{f}$ the mutant N189Y residue, with the sidechains rendered in spheres to distinguish them from the molecular surface. (From Varanda et al., Journal of General Virology 92, 2209-2213, 2011)

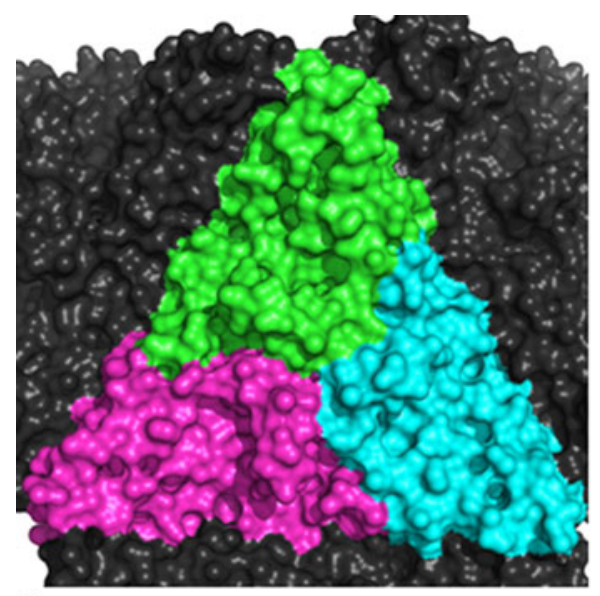

a

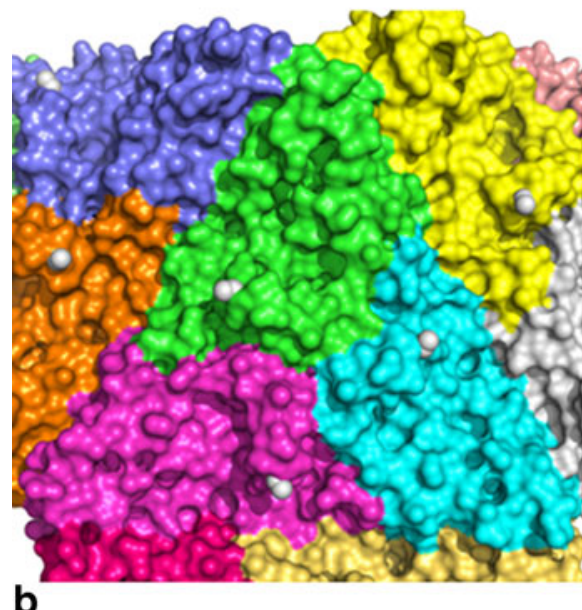

b

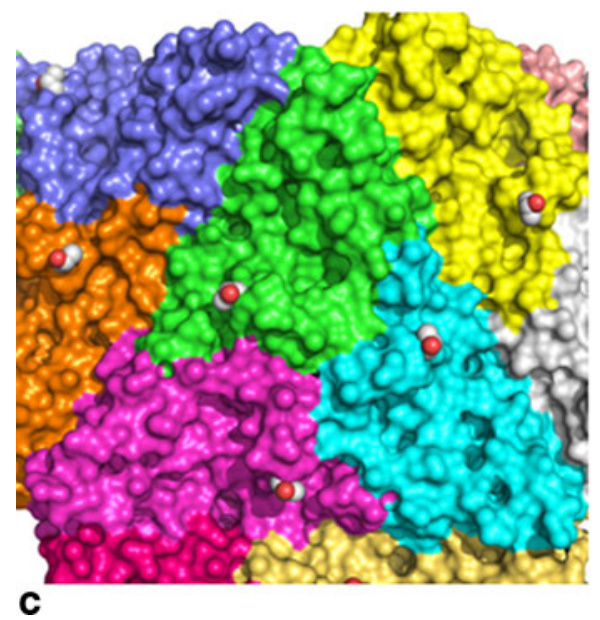

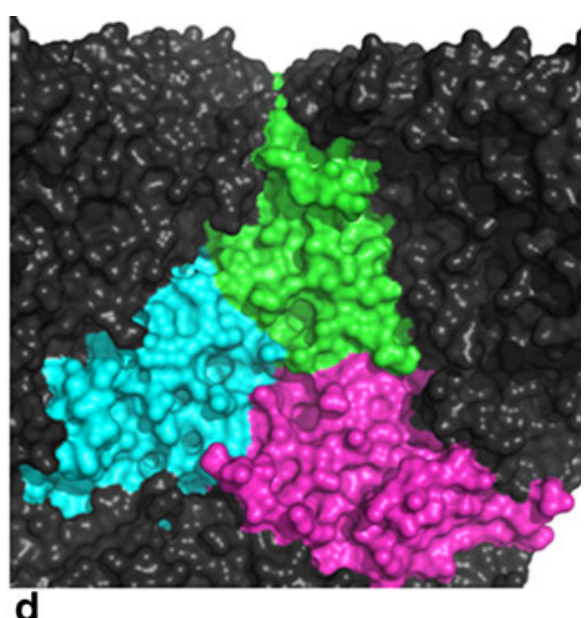

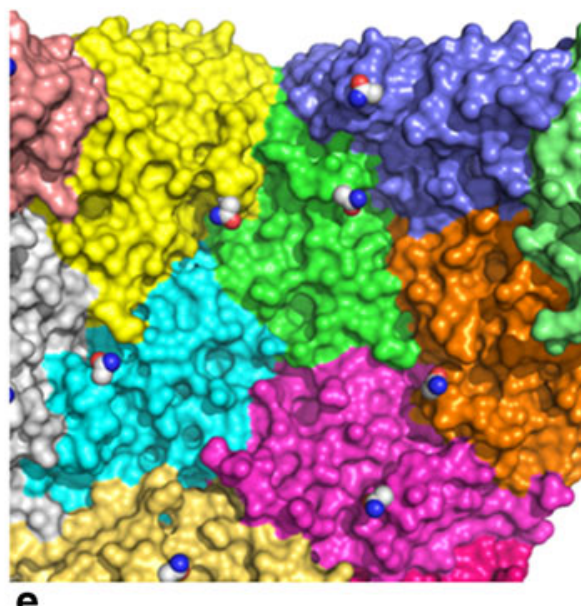

e

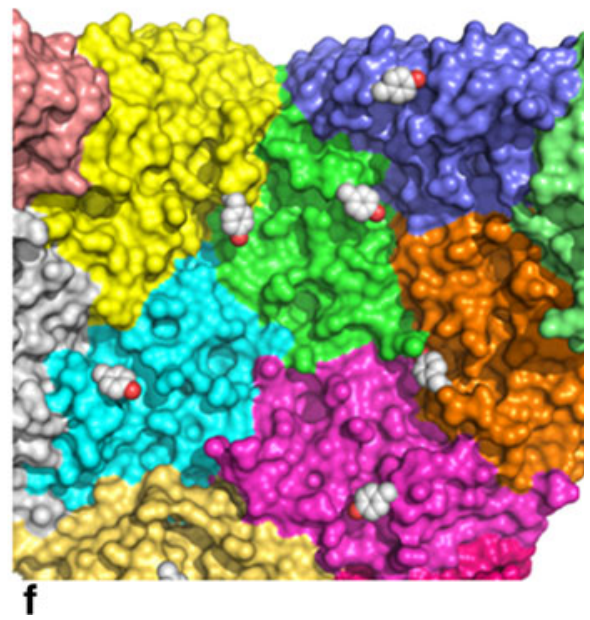




\section{Concluding remarks}

The presence of multiple necrovirus infections in field-grown olive trees provide ample opportunities for the emergence of new species through recombination, as was the case of OMMV, or variants through mutation, both type of events being major driving forces in the evolution of plant viruses. New viral species or variants that possess the ability to be vectored by fungi, as Olpidium species, and transmitted at high rates, are best fitted to encounter and adapt to new hosts or environments and spread more efficiently by soil and water movement. Others may be reliant on only the vegetative propagation of the crop for dissemination and survival. The recent finding that OMMV is fungally transmitted bears practical implications in its epidemiology that needs to be taken into consideration in designing effective control strategies. On the other hand, understanding the interactions occurring in plants with multiple infections is an attractive research field that need new approaches and renewed attention.

Acknowledgments We specifically acknowledge the longterm collaboration with the good friend and colleague Investigador Fausto A. Leitão who have stimulated our studies on the sanitary status of the olive crop in Portugal. Carla Marisa R. Varanda is recipient of a $\mathrm{PhD}$ fellowship from Fundação para a Ciência e a Tecnologia (FCT), SFRH/BD/29398/2006

\section{References}

Al Abdullah, A., El Beaino, T., Saponari, M., Hallak, H., \& Digiaro, M. (2005). Preliminary evaluation of the status of olive-infecting viruses in Syria. OEPP/EPPO Bulletin, 35, 249-252.

Bertolini, E., Olmos, A., Martínez, M. C., Gorris, M. T., \& Cambra, M. (2001). Single-step multiplex RT-PCR for simultaneous and colourimetric detection of six RNA viruses in olive trees. Journal of Virological Methods, 96, $33-41$.

Borodynko, N., Hasiów-Jaroszewska, B., \& Pospieszny, H. (2010). Identification and characterization of an Olive latent virus 1 isolate from a new host: Solanum lycopersicum. Journal of Plant Pathology, 92(3), 789-792.

Cardoso, J. M. S. (2009). Molecular characterization of necroviruses isolated from Olea europaea $L$. PhD Thesis, University of Évora, $138 \mathrm{p}$.

Cardoso, J. M. S., Félix, M. R., Oliveira, S., \& Clara, M. I. E. (2004). A Tobacco necrosis virus $D$ isolate from Olea europaea L.: viral characterization and coat protein sequence analysis. Archives of Virology, 149, 1129-1138.
Cardoso, J. M. S., Félix, M. R., Clara, M. I. E., \& Oliveira, S. (2005). The complete genome sequence of a new necrovirus isolated from Olea europaea L. Archives of Virology, 150, 815-823.

Cardoso, J. M. S., Félix, M. R., Clara, M. I. E., \& Oliveira, S. (2009). Complete genome sequence of a Tobacco necrosis virus $D$ isolate from olive trees. Archives of Virology, 154, 1169-1172.

Castellano, M. A., Loconsole, G., Grieco, F., Di Sansebastiano, G. P., \& Martelli, G. P. (2005). Subcellular localization and immunodetection of movement proteins of olive latent virus 1. Archives of Virology, 150, 1369-1381.

Çinar, A., Kersting, U., Önelge, N., Korkmaz, S., \& Sas, G. (1993). Citrus virus and virus-like diseases in the Eastern Mediterranean region of Turkey. Proceedings 12th IOCV Conference, Riverside 1993, USA, 397-400.

Clara, M. I. E., Rei, F., Félix, M. R., Leitão, F. A., Serrano, J. F., \& Potes, M. F. (1997). Viruses affecting Olea europaea L. crop and diagnostic techniques. Olivae, 66, 56-60.

Clark, M. F., \& Adams, A. M. (1977). Characteristics of the microplate method of enzyme-linked immunosorbent assay for the detection of plant viruses. Journal of General Virology, 34, 475-483.

Coutts, R. H. A., Rigden, J. E., Slabas, A. R., Lomonossoff, G. P., \& Wise, P. J. (1991). The complete nucleotide sequence of Tobacco necrosis virus strain-D. Journal of General Virology, 72, 1521-1529.

EEC Directive (1993). Commission Directive 93/48/EEC of 23 June 1993 setting out the schedule indicating the conditions to be met by fruit plant propagating material and fruit plants intended for fruit production, pursuant to Council Directive 92/34/EEC.

El Air, M., Mahfoudi, N., Digiaro, M., Najjar, A., \& Elbeaino, T. (2011). Detection of Olive-infecting viruses in Tunisia. Journal of Phytopathology, 159(4), 201-238.

Fadel, C., Digiaro, M., Choueiri, E., El Beaino, T., Saponari, M., Savino, V., \& Martelli, G. P. (2005). On the presence and distribution of olive viruses in Lebanon. OEPP/EPPO Bulletin, 35, 33-36.

Falquet, L., Pagni, M., Bucher, P., Hulo, N., Sigrist, C. J., Hofman, \& Bairoch, K. A. (2002). The PROSITE database, its status in 2002. Nucleic Acids Research, 30, 235-238.

Félix, M.R.F. (2007). Caracterização biomolecular de Olive latent virus 1 isolado de Olea europaea L. Tese de Doutoramento, Universidade de Évora, 114 p.

Félix, M.R, \& Clara, M.I.E. (1998). Características biológicas e bioquimicas da estirpe G1, do Necrovirus Olive latent 1 isolado de Olea europaea L.. Actas da $2^{a}$ Reunião Bienal da Sociedade Portuguesa de Fitopatologia, pp 67.

Félix, M. R. F., \& Clara, M. I. E. (2008). Characterization and diagnosis of viruses occurring on Olea europaea L. In G. P. Rao, R. A. Valverde, \& C. I. Dovas (Eds.), Techniques in diagnosis of plant viruses (pp. 189-226). Huston, USA: Studium Press LLC.

Félix, M. R., Clara, M. I., Leitão, F., \& Serrano, J. (2002). Virus incidence in four Olea europaea cultivars evaluated by mechanical inoculation and immunological assays. Acta Horticulturae, 586(2), 721-724.

Félix, M.R., Varanda, C.M.R., Cardoso, J.M.S., \& Clara, M.I.E. (2004). Soil transmission of an olive isolate of Olive latent 
virus 1. 15th International Plant Protection Congress, Beijing, China, Book of Abstracts p 447.

Félix, M. R., Cardoso, J. M. S., Oliveira, S., \& Clara, M. I. E. (2005a). Viral properties, primary structure and phylogenetic analysis of the coat protein of an Olive latent virus 1 isolate from Olea europaea L. Virus Research, 108, 195198.

Félix, M. R., Cardoso, J. M. S., Varanda, C. M. R., Oliveira, S., \& Clara, M. I. E. (2005b). Complete nucleotide sequence of an Olive latent virus 1 isolate from olive trees. Archives of Virology, 150, 2403-2406.

Félix, M. R., Cardoso, J. M. S., \& Clara, M. I. E. (2006a). Single Strand Conformation Polymorphism analysis of Olive latent virus 1 isolates from Olea europaea L. Proceedings of the Olivebioteq 2006- Second International Seminar "Biotechnology and Quality of Olive Tree Products around the Mediterranean Basin", Vol II, 243-246.

Félix, M. R., Varanda, C., Cardoso, J. M. S., \& Clara, M. I. E. (2006b). Plant root uptake of Olive latent virus 1 and Olive mild mosaic in single and mixed infections (pp. 516-517). Rhodes, Greece: Proceedings of XII MPU Congress.

Félix, M. R., Cardoso, J. M. S., Oliveira, S., \& Clara, M. I. (2007). Biological and molecular characterization of Olive latent virus 1. Plant Viruses, 1, 170-177.

Gallitelli, D., \& Savino, V. (1985). Olive latent virus 1, a single RNA spherical virus isolated from olive in Apulia (southern Italy). Annals of Applied Biology, 106, 295-303.

Grieco, F., Alkowni, R., Saponari, M., Savino, V., \& Martelli, G. P. (2000). Molecular detection of olive viruses. Bulletin OEPP/EPPO, 30, 469-473.

Grieco, F., Parrella, G., \& Vovlas, C. (2002). An isolate of olive latent virus 2 infecting castor bean in Greece. Journal of Plant Pathology, 84, 129-131.

Kakani, K., Sgro, J. Y., \& Rochon, D. (2001). Identification of specific Cucumber necrosis virus coat protein amino acids affecting fungus transmission and zoospore attachment. Journal of Virology, 75, 5576-5583.

Kakani, K., Reade, R., \& Rochon, D. (2004). Evidence that vector transmission of a plant virus requires conformational change in virus particles. Journal of Molecular Biology, 338, 507-517.

Kanematsu, S., Taga, Y., \& Morikawa, T. (2001). Isolation of Olive latent virus 1 from tulip in Toyama Prefecture. Journal of General Plant Pathology, 67, 333-334.

Kassanis, B., \& Macfarlane, I. (1964). Transmission of Tobacco Necrosis Virus by zoospores of Olpidium brassicae. Journal of General Microbiology, 36, 79-93.

Lobão, D.L., Félix, M.R., Clara, M.I.E., Oliveira, S., Leitão, F. A., \& Serrano, J.F. (2002). Detection of Olive latent virus 1 in Olea europaea L. tissues by reverse transcriptionpolymerase chain reaction. Book of Abstracts XIII Congresso Nacional de Bioquímica, Lisboa, 102 p.

Loconsole, G., Saponari, M., Faggioli, F., Albanese, G., Bouyahia, H., Elbeaino, T., Materazzi, A., Nuzzaci, M., Prota, V., Romanazzi, G., Trisciuzzi, N., \& Savino, V. (2010). Inter-laboratory validation of PCR-based protocol for detection of olive viruses. Bulletin OEPP/EPPO, 40, 423-428.

Louro, T. J. F. M. (2004). Caracterização de um isolado viral de Olea europaea L., produção de anticorpos policlonais específicos, e aplicação de métodos de diagnóstico. Tese de Mestrado Luso-Brasileiro em Gestão e Políticas Ambientais, Universidade de Évora, Évora, 91pp.

Martelli, G. P. (1999). Infectious disease and certification of olive: an overview. Bulletin OEPP/EPPO, 29, 127-133.

Martelli, G. P., Sabanadzovic, S., Savino, V., Abu-Zurayk, A. R., \& Masannat, M. (1995). Virus-like disease and viruses of olive in Jordan. Phytopathologia Mediterranea, 34, 133-136.

Martelli, G. P., Yilmaz, M. A., Savino, V., Baloglu, S., Grieco, F., Guldur, M. E., Greco, N., \& Lafortezza, R. (1996). Properties of a citrus isolate of olive latent virus 1, a new necrovirus. European Journal of Plant Pathology, 102, 527-536.

Merciega, V., Boscia, \& Savino, D. V. (1996). Comparison of five isolates of olive latent virus 1. Phytopathologia Mediterranea, 35, 1-8.

Mochizuki, T., Ohnishi, J., Ohki, T., Kanda, A., \& Tsuda, S. (2008). Amino acid substitution in the coat protein of Melon necrotic spot virus causes loss of binding to the surface of Olpidium bornovanus zoospores. Journal of General Plant Pathology, 74(2), 176-181.

Molnar, A., Havelda, Z., Dalmay, T., Szutorisz, H., \& Burgyan, J. (1997). Complete nucleotide sequence of tobacco necrosis virus strain D-H and genes required for RNA replication and virus movement. Journal of General Virology, 78, 1235-1239.

Oda, Y., Saeki, K., Takahashi, Y., Maeda, T., Naitow, H., Tsukihara, T., \& Fukuyama, K. (2000). Crystal structure of tobacco necrosis virus at $2.25 \AA$ Á resolution. Journal of Molecular Biology, 300, 153-169.

Pantaleo, V., Grieco, F., Castellano, M. A., \& Martelli, G. P. (1999). Synthesis of infectious transcripts of olive latent virus 1: genes required for RNA replication and virus movement. Archives of Virology, 144, 1071-1079.

Pantaleo, V., Saponari, M., \& Gallitelli, D. (2001). Development of a nested PCR protocol for detection of oliveinfecting virus in crude extracts. Journal of Plant Pathology, 83(2), 143-146.

Pantaleo, V., Grieco, F., Di Franco, A., \& Martelli, G.P. (2006). The role of the C-terminal region of Olive latent virus 1 coat protein in the host systemic infection. Archives of Virology 151, 1973-1983

Pham, K., Lemmers, M., van Doorn, J., \& Derks, T. (2009). Revision of taxonomy of the virus causing Augusta disease in tulips in The Netherlands. Fifth joint meeting of the DPG working group 'Viruskrankheiten der pflanzen' and the 'Netherlandse kring voor plantevirologie', Hamburg, 8-9 ${ }^{\text {th }}$ of April.

Poch, O., Sauvaget, I., Delarue, M., \& Tordo, N. (1989). Identification of four conserved motifs among the RNAdependent polymerase encoding elements. EMBO Journal, $8,3867-3874$.

Regenmortel, M. H. V., Fauquet, C. M., Bishop, D. H. L., Carstens, E. B., Estes, M. K., Lemon, S. M., Maniloff, J., Mayo, M. A., McGeoch, D. J., Pringle, C. R., \& Wickner, R. B. (2000). Virus taxonomy. San Diego, California, USA: Academic Press.

Rei, F.T. (1995). A aplicação do método de isolamento de cadeias duplas de RNA (double-stranded RNA-dsRNA) no diagnóstico de infecções virais em Olea europaea L.. Tese de Mestrado em Protecção Integrada, Instituto Superior de Agronomia, Lisboa, 91 pp. 
Rubio, L., Ayllón, M. A., Gerri, J., Pappu, H., Niblett, C., \& Moreno, P. (1996). Differentiation of Citrus tristeza Closterovirus (CTV) isolates by single-strand conformation polymorphism analysis of the coat protein gene. Annals of Applied Biology, 129, 479-489.

Sabanadzovic, S., Abou-Ghanem, N., La Notte, P., Savino, V., \& Martelli, G. P. (1999). Partial molecular characterization and RT-PCR detection of a putative closterovirus associated with olive leaf yellowing. Journal of Plant Pathology, 81(1), 37-45.

Saponari, M., El Beaino, T., Grieco, F., Savino, V., \& Martelli, G. P. (2001). Diagnosi di virus dell' olivo mediante l'impiego degli RNA a doppia elica. Atti Progetto POM A, 32, 793-797.

Saponari, M., Alkowni, R., Grieco, F., Pantaleo, V., Savino, V., \& Martelli, G. P. (2002). Detection of olive-infecting viruses in Mediterranean Basin. Acta Horticulturae, 586 (2), 787-790.

Saponari, M., Savino, V., \& Martelli, G. P. (2002). Transmissioni per seme dei virus dell'olivo. Frutticoltura, 4, 103-105.

Savino, V., Sabanadzovic, Sacrito, S. G., Laviola, C., \& Martelli, G. P. (1996). Due giallumi dell' olivo di possible origine virale in Sicilia. Informatore Fitopatologico, 5, 55-59.

Temmink, J. H. M., Campbell, R. N., \& Smith, P. R. (1970). Specificity and site of in vitro acquisition of Tobacco necrosis virus by zoospores of Olpidium brassicae. Journal of General Virology, 9, 201-213.

Varanda, C.M.R., Félix, M.R.F., Leitão, F., Sismeiro, R., \& Clara, M.I.E (2006). Application of Reverse Transcription - Polymerase Chain Reaction to screen a collection of clones of Olea europaea L. for the presence of necroviruses (Tombusviridae). $8^{\text {th }}$ Conference of the European Foundation for Plant Pathology \& British Society of Plant Pathology Presidential Meeting 2006, Copenhagen, Denmark.

Varanda, C. M. R., Félix, M. R. F., \& Clara, M. I. E. (2008). DsRNA analysis and RT-PCR assays to evaluate viral infections: the case of necroviruses in olive. Journal of Plant Pathology, 90(2), 385.

Varanda, C.M.R, Cardoso, J.M.S, Félix, M.R.F, Oliveira, S., \& Clara, M.I.E (2009). Evaluation of necroviruses occurence by specific RT-PCR in olive. $4^{\text {th }}$ European Meeting of the IOBC/WPRS working Group Integrated Protection of Olive Crops, Cordoba, Spain, Book of Abstracts, p 104.

Varanda, C. M. R., Cardoso, J. M. S., Félix, M. R. F., Oliveira, S., \& Clara, M. I. E. (2010). Multiplex RT-PCR for detection and identification of three necroviruses that infect olive trees. European Journal of Plant Pathology, 127, 161-164.

Varanda, C. M. R., Félix, M. R., Soares, C. M., Oliveira, S., \& Clara, M. I. E. (2011). Specific amino acids of Olive mild mosaic virus coat protein are involved on transmission by Olpidium brassicae. Journal of General Virology, 92, 2209-2213.

Varanda, C. M. R., Silva, M. S. M. R., Félix, M. R., \& Clara, M. I. E. (2011). Evidence of Olive mild mosaic virus transmission by Olpidium brassicae. European Journal of Plant Pathology, 130, 165-172.

Youssef, S. A., Moawed, S. M., El-Sayed, M., \& Shalaby, A. A. (2010). Detection of olive tree viruses in Egypt by onestep RT-PCR. 21st International Conference on Virus and other Graft Transmissible Diseases of Fruit Crops, JuliusKühn-Archiv, 427, 51-55. 